\title{
Coronary heart disease mortality in China: age, gender, and urban-rural gaps during epidemiological transition
}

\author{
Guohong Jiang, ${ }^{1}$ Dezheng Wang, ${ }^{1}$ Wei Li, ${ }^{1}$ Yi Pan, ${ }^{1}$ \\ Wenlong Zheng, ${ }^{1}$ Hui Zhang, ${ }^{1}$ and Yan V. Sun ${ }^{2}$
}

Suggested citation Jiang G, Wang D, Li W, Pan Y, Zheng W, Zhang H, et al. Coronary heart disease mortality in China: age, gender, and urban-rural gaps during epidemiological transition. Rev Panam Salud Publica. 2012;31(4):317-24.

ABSTRACT Objective. To examine and describe coronary heart disease (CHD) mortality and its pattern of change (trend) by sex, age, and area of residence (urban versus rural) in Tianjin, China, within the context of epidemiological transition, and compare it with current trends in the Americas and Europe.

Methods. A total of 104393 cases of CHD death in Tianjin occurring between 1999 and 2008 were monitored. Death due to CHD was coded using International Classification of Diseases (ICD) standards (ninth and tenth revisions). Standardized CHD mortality rates and their trends were analyzed by age, sex, and urban versus rural residence.

Results. During the 10-year study period, the proportion of total deaths due to CHD in Tianjin increased significantly (from 16\% to 24\%) and age-standardized CHD mortality increased slightly (with no statistical differences), in contrast to CHD mortality trends in various countries in the Americas and Europe, which are declining. No difference was found in Tianjin's CHD mortality trend by sex. Overall CHD mortality was consistently higher among older age groups, males, and residents of urban areas. The proportion of $C H D$ deaths occurring outside hospitals was $55.81 \%$, with a declining trend over the study period. Rural areas had a higher proportion of outside-hospital CHD mortality than urban areas, but no difference was found across age groups.

Conclusions. From 1999 to 2008, CHD mortality in Tianjin varied by sex, age, and urban versus rural area of residence. Future research to identify $\mathrm{CHD}$ risk factors and the populations most vulnerable to the disease is recommended to help strengthen $C H D$ prevention. Strategies for CHD control similar to those used in various developed countries in the Americas and Europe should be developed to reduce the CHD burden in China.

Key words Coronary disease, mortality; health transition; risk factors; China.

Since 1990, more people have died from coronary heart disease (CHD) than from any other cause worldwide (1).

\footnotetext{
1 Tianjin Centers for Disease Control and Prevention, Tianjin, China. Send correspondence to: Guohong Jiang, jiangguohong@263.net

2 Department of Epidemiology, School of Public Health, University of Michigan, Ann Arbor, Michigan, United States of America.
}

While genetic factors play a part, at least $80 \%$ of those who die from CHD have one or more of the major risk factors influenced by lifestyle, such as diet and physical activity (1). According to the World Health Organization (WHO), 3.8 million men and 3.4 million women worldwide die each year from CHD. Death rates from CHD have de- creased in many developed countries (2, $3)$. This decline is attributed to improved prevention, diagnosis, and treatment, particularly reduced cigarette smoking among adults, and lower average levels of blood pressure and blood cholesterol $(2,4)$. Currently, more than $60 \%$ of the global burden of CHD occurs in developing countries, where $82 \%$ of the future 
increase in CHD mortality is expected to occur (1). However, most of the epidemiological research providing the scientific base for effective prevention and control of CHD-including cohort studies on CHD onset and death, and CHD mortality trend and distribution-has been conducted in Europe, the United States, and Japan $(1,5)$.

In terms of demographics, China is the largest country in the world, representing one-fifth of the global population. In recent decades the burden of CHD mortality has grown, with more than 700000 Chinese dying from CHD in 2002 (1). Although a limited number of studies on ischemic heart disease (IHD) and CHD have been reported for Chinese samples (6-9), national characteristics and patterns of change (trends) of CHD mortality have not been well documented at the population level over the past decade-a period of dramatic socioeconomic development in China that has resulted in shifting disease patterns known as epidemiological transition. To help fill these gaps, the current study examined the distribution and trends of CHD mortality in modern China, by sex, age, and area of residence (urban versus rural), within the context of epidemiological transition. Given China's large population, Tianjin, a city with a residential population of more than 10 million, was chosen as the study site. Current trends in CHD mortality in various countries in the Americas and Europe were also examined for the sake of comparison.

Tianjin is one of the three largest cities in China, with about 4 million urban and 6 million rural residents. CHD has been the first or second leading cause of death in Tianjin in the last two decades. In this study, 104393 cases of CHD death in Tianjin from 1999 to 2008 were analyzed using validated death certificate data from a surveillance system managed by the Tianjin Centers for Disease Control and Prevention (TJCDC). The study compared the secular trend of CHD mortality by age group, sex, and area of residence (urban versus rural) over the 10-year period.

\section{MATERIALS AND METHODS}

Death data were recorded from death certificates collected through the Causeof-Death Registration System (CDRS) maintained by the TJCDC, which monitors the entire residential population in Tianjin. According to the regulations of the CDRS, which has been approved by the TJCDC Ethics Committee, all death certificates entered into the database must be completed by physicians in hospitals or community clinical centers. At the primary level, district or county CDCs oversee and check the daily reported deaths, on a case-by-case basis. Deaths that occur outside hospitals are included in the CDRS based on information obtained from household interviews and home visits by community clinicians using the verbal autopsy (VA) approach recommended by $\mathrm{WHO}$. The district or county CDCs are responsible for collecting and verifying the medical certificates for all outside-hospital deaths and adding them to the CDRS on a weekly basis. The TJCDC carries out secondary data verification, along with investigation of missing reports, as well as quality control, sorting, and analysis of the data. It also provides technical training and support to staff involved in the reporting process.

Each death certificate includes 53 data fields, including age, sex, and cause of death, as well as the home address used to classify area of residence as urban or rural. The mortality rates used in the study were calculated and standardized using the WHO world standard population for the year 2000. About $40 \%$ of the residential population in Tianjin lives in urban areas and about $60 \%$ live in rural areas. The migrant population was not included in the study.

FIGURE 1. Trend in coronary heart disease mortality as proportion of all causes of death, Tianjin, China, 1999-2008

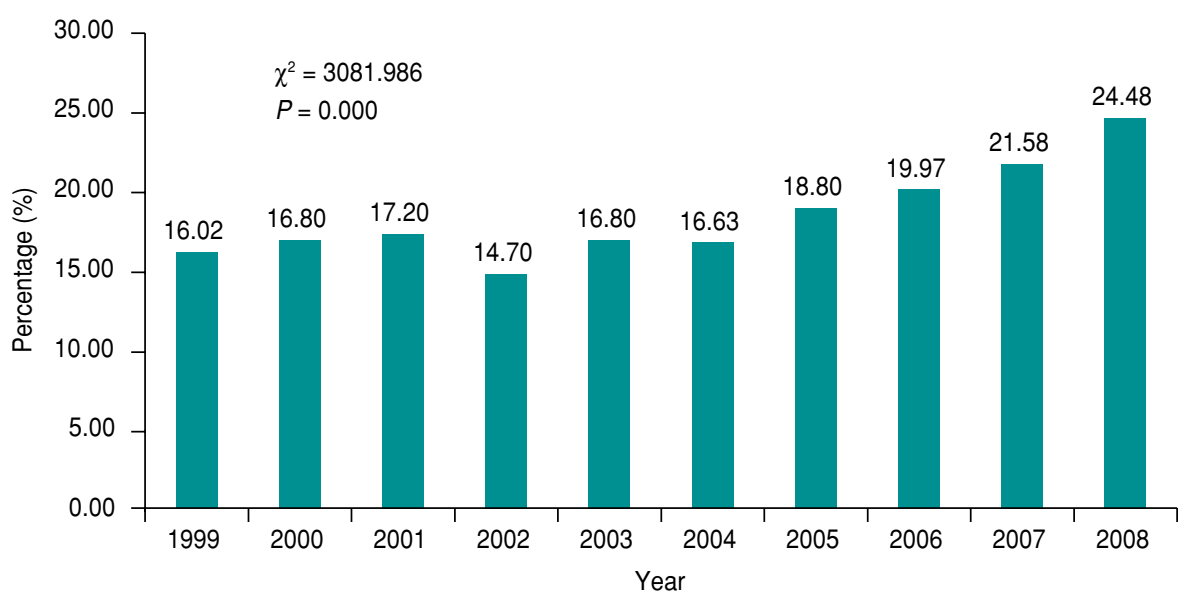

Using the confirmed cause of death of each death certificate, all cases of death due to CHD between 1999 and 2008 in Tianjin were identified. As per the standards of the WHO International Classification of Diseases (Ninth Revision or ICD-9, for 1999-2002, and Tenth Revision or ICD-10, for 2003-2008), death due to CHD includes codes 410-414, 429.2, and 997.10 (in ICD-9), and codes I20-I25 (in ICD-10). Age-standardized CHD mortality was calculated for each year. Trends of overall death rates and the proportion from CHD were calculated using linear regression and the chi-square $\left(\chi^{2}\right)$ test. SPSS version 11.0 (IBM, Somers, NY, USA) was used for statistical calculations.

\section{RESULTS}

A total of $104393 \mathrm{CHD}$ deaths-55 380 males $(53.05 \%)$ and 49013 females $(46.95 \%)$, and 67010 urban $(64.19 \%)$ and 37383 rural $(35.81 \%)$ residents-were recorded and validated in Tianjin's CDRS, which covers the entire residential population between 1999 and 2008. Overall mortality from CHD stayed the same or increased over the study period, in contrast to current trends in CHD mortality in various countries in the Americas and Europe, which are declining.

\section{Trend in CHD mortality as proportion of all causes of death}

The annual proportion of death due to CHD during the 10-year study period is addressed in Figure 1. As shown, the proportion for 2008 was $50 \%$ higher than 
that for 1999. This climbing trend did not differ by sex $(P<0.01)$.

\section{Epidemiological characteristics}

Age-standardized CHD mortality rates between 1999 and 2008 in Tianjin are summarized in Table 1 . There were no statistical differences over the 10-year study period, based on liner regression analysis $(P>0.05)$, but the overall CHD mortality rate increased from 95.29 (per 100000 individuals per year) in 1999 to 103.36 (per 100000 individuals per year) in 2008.

Sex- and area-of-residence-specific CHD mortality rates showed the same pattern. Between 1999 and 2008, men in Tianjin had a higher CHD mortality rate than women. The male:female CHD mortality rate ratio ranged from 1.20 to 1.55. During the same period, CHD mortality rates for urban areas were consistently higher than those for rural areas, but the rate at which the urban:rural ratio dropped during the study period was significantly lower $(P<0.01)$.

\section{Distribution by sex and urban versus rural area}

As shown in Figure 2, the sex-specific CHD mortality rates in urban areas of Tianjin were consistently higher than those in rural areas throughout the study period. However, CHD mortality appeared to be increasing over time for both male and female populations in rural areas $(P<0.05)$. Within both urban and rural populations, male CHD mortality rates were higher than those for females throughout the 10-year period. From the year 2002 to 2008 , the trend for all subgroups except females in urban areas grew continuously $(P<0.05)$.

\section{Distribution by age group and sex}

Age is a strong predictor of CHD. Table 2 shows the sex-specific mortality rate for six age groups ( $<35$ years, 35-44, 45-54, 55-64, 65-74, and $\geq 75$ years). For both sexes, mortality rates rose with increasing age throughout the 10 -year study period, based on the linear regression test $(P<0.05)$. With some fluctuation over the study period, overall sex-specific CHD mortality rates decreased in most age groups, whereas the rate for men 75 years and older increased (from $1645.23 / 100000 /$ year in 1999 to $1925.49 / 100000 /$ year in 2008). The rate for women 75 years and older increased from $1461.40 / 100000 /$ year in 1999 to $1883.52 / 100000 /$ year in 2008, and the rate for men 35-44 years old rose from $21.2 / 100000 /$ year to $30.75 / 100000 /$ year over the same period.

Males in Tianjin had an unambiguously higher CHD mortality rate versus females, particularly those in the productive population (35-54 years old), among whom mortality due to CHD was 2-3.5fold higher versus females in the same age group throughout the 10-year period.

\section{Proportion of outside-hospital deaths by sex, age group, and urban versus rural residence}

The proportion of annual outsidehospital deaths due to CHD during the

TABLE 1. Trend in age-standardized coronary heart disease mortality ${ }^{\mathrm{a}}$ by sex and area of residence (urban versus rural), Tianjin, China, 1999-2008

\begin{tabular}{|c|c|c|c|c|c|c|c|}
\hline Year & $\begin{array}{l}\text { Total } \\
(\%)\end{array}$ & $\begin{array}{c}\text { Male } \\
(\%)\end{array}$ & $\begin{array}{c}\text { Female } \\
(\%)\end{array}$ & $\begin{array}{l}\text { Male:female } \\
\text { ratio }\end{array}$ & $\begin{array}{l}\text { Urban } \\
(\%)\end{array}$ & $\begin{array}{c}\text { Rural } \\
(\%)\end{array}$ & $\begin{array}{l}\text { Urban:rural } \\
\text { ratio }\end{array}$ \\
\hline 1999 & $\begin{array}{c}95.3 \\
(93.3,97.3)\end{array}$ & $\begin{array}{c}107.8 \\
(104.8,110.8)\end{array}$ & $\begin{array}{c}82.8 \\
(80.1,85.4)\end{array}$ & 1.3 & $\begin{array}{c}125.1 \\
(121.8,128.4)\end{array}$ & $\begin{array}{c}70.9 \\
(68.5,73.4)\end{array}$ & 1.8 \\
\hline 2000 & $\begin{array}{c}99.3 \\
(97.2,101.3)\end{array}$ & $\begin{array}{c}110.5 \\
(107.4,113.5)\end{array}$ & $\begin{array}{c}88.1 \\
(85.4,90.9)\end{array}$ & 1.3 & $\begin{array}{c}130.2 \\
(126.9,133.5)\end{array}$ & $\begin{array}{c}74.1 \\
(71.6,76.6)\end{array}$ & 1.8 \\
\hline 2001 & $\begin{array}{c}95.7 \\
(93.6,97.7)\end{array}$ & $\begin{array}{c}106.9 \\
(103.9,109.9)\end{array}$ & $\begin{array}{c}84.4 \\
(81.8,87.1)\end{array}$ & 1.3 & $\begin{array}{c}121.8 \\
(118.6,125.1)\end{array}$ & $\begin{array}{c}75.6 \\
(73.0,78.1)\end{array}$ & 1.6 \\
\hline 2002 & $\begin{array}{c}76.6 \\
(74.8,78.4)\end{array}$ & $\begin{array}{c}86.0 \\
(83.3,88.6)\end{array}$ & $\begin{array}{c}67.2 \\
(64.8,69.6)\end{array}$ & 1.3 & $\begin{array}{c}98.8 \\
(95.9,101.7)\end{array}$ & $\begin{array}{c}58.9 \\
(56.7,61.1)\end{array}$ & 1.7 \\
\hline 2003 & $\begin{array}{c}86.5 \\
(84.6,88.4)\end{array}$ & $\begin{array}{c}94.2 \\
(91.4,97.0)\end{array}$ & $\begin{array}{c}78.8 \\
(76.2,81.4)\end{array}$ & 1.2 & $\begin{array}{c}116.1 \\
(112.9,119.2)\end{array}$ & $\begin{array}{c}61.5 \\
(59.2,63.8)\end{array}$ & 1.9 \\
\hline 2004 & $\begin{array}{c}79.6 \\
(77.8,81.4)\end{array}$ & $\begin{array}{c}88.1 \\
(85.4,90.8)\end{array}$ & $\begin{array}{c}71.1 \\
(68.7,73.5)\end{array}$ & 1.2 & $\begin{array}{c}99.9 \\
(97.0,102.7)\end{array}$ & $\begin{array}{c}64.8 \\
(62.4,67.1)\end{array}$ & 1.5 \\
\hline 2005 & $\begin{array}{c}86.1 \\
(84.3,88.0)\end{array}$ & $\begin{array}{c}95.5 \\
(92.7,98.3)\end{array}$ & $\begin{array}{c}76.8 \\
(74.3,79.3)\end{array}$ & 1.2 & $\begin{array}{c}101.5 \\
(98.6,104.4)\end{array}$ & $\begin{array}{c}78.0 \\
(75.4,80.6)\end{array}$ & 1.3 \\
\hline 2006 & $\begin{array}{c}105.1 \\
(103.1,107.0)\end{array}$ & $\begin{array}{c}127.8 \\
(124.7,130.8)\end{array}$ & $\begin{array}{c}82.3 \\
(79.9,84.8)\end{array}$ & 1.6 & $\begin{array}{c}127.7 \\
(124.6,130.8)\end{array}$ & $\begin{array}{c}90.9 \\
(88.3,93.5)\end{array}$ & 1.4 \\
\hline 2007 & $\begin{array}{c}92.2 \\
(90.3,94.1)\end{array}$ & $\begin{array}{c}102.3 \\
(99.4,105.1)\end{array}$ & $\begin{array}{c}82.2 \\
(79.6,84.7)\end{array}$ & 1.3 & $\begin{array}{c}110.8 \\
(107.8,113.7)\end{array}$ & $\begin{array}{c}81.3 \\
(78.7,83.9)\end{array}$ & 1.4 \\
\hline 2008 & $\begin{array}{c}103.4 \\
(101.3,105.4)\end{array}$ & $\begin{array}{c}115.4 \\
(112.4,118.5)\end{array}$ & $\begin{array}{c}91.3 \\
(88.6,94.0)\end{array}$ & 1.3 & $\begin{array}{c}125.5 \\
(122.3,128.6)\end{array}$ & $\begin{array}{c}89.8 \\
(87.1,92.5)\end{array}$ & 1.4 \\
\hline$b^{b}$ & 0.557 & 0.837 & 0.277 & 0.006 & -0.674 & 2.167 & -0.052 \\
\hline$P$ & 0.628 & 0.588 & 0.753 & 0.621 & 0.644 & 0.068 & 0.007 \\
\hline
\end{tabular}


FIGURE 2. Trend in age-standardized coronary heart disease (CHD) mortality by sex and area of residence (urban versus rural), Tianjin, China, 1999-2008 ${ }^{\mathrm{a}}$

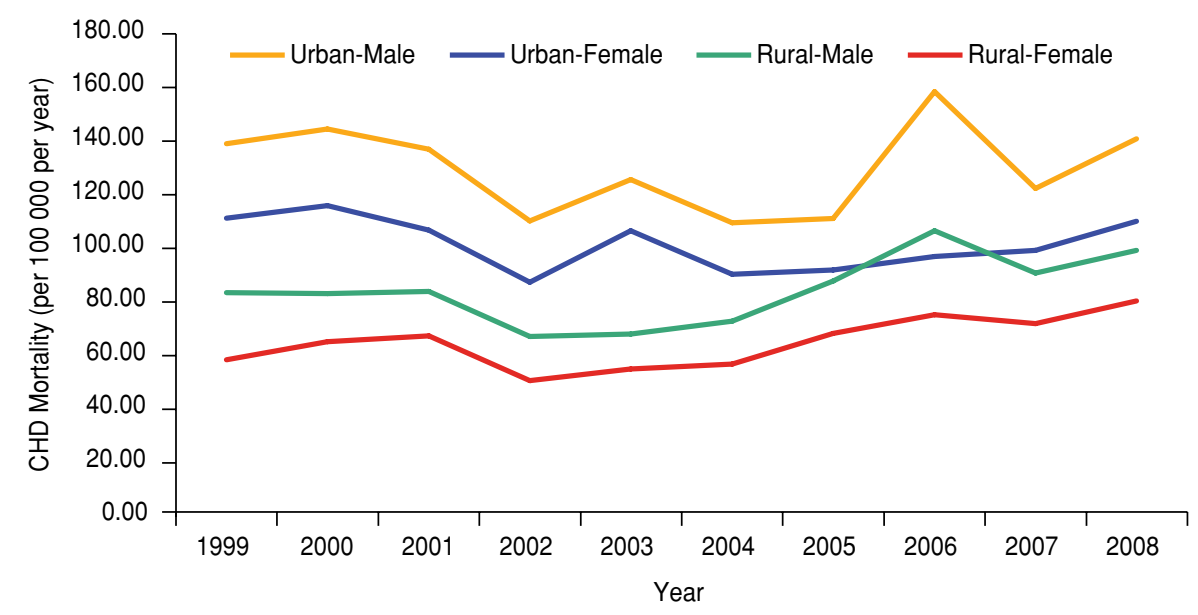

a Chi-square test for trend: $(1999-2008)$ : rural-male, $\chi^{2}=5.0792, P=0.0242$; rural-female, $\chi^{2}=5.3843, P=0.0203 ;(2002-$
2008): rural-male, $\chi^{2}=12.9968, P=0.0003$; rural-female, $\chi^{2}=10.9349, P=0.0009 ;(1999-2008)$ : urban-male, $\chi^{2}=0.0444$,
$P=0.8330 ;$ urban-female, $\chi^{2}=0.9561, P=0.3282 ;(2002-2008)$ : urban-male, $\chi^{2}=5.1379, P=0.0234 ;$ urban-female, $\chi^{2}=$
1.3331, $P=0.2486$.

10-year study period is addressed in Table 3, which shows that the average proportion of these deaths (among all CHD deaths) was more than $50 \%$, and underwent a declining trend across the study period $(P<0.01)$. Sex- and areaof-residence-specific proportions had a similar pattern $(P<0.01)$. Women experienced a higher proportion of outsidehospital CHD deaths compared to men, and the proportions of outside-hospital CHD deaths in rural areas were consistently higher than those for urban areas during the same period. The proportion of age-specific outside-hospital CHD deaths fluctuated from $40 \%$ to $70 \%$ and showed a downward trend among those more than 55 years old throughout the study period $(P<0.01)$.

\section{Comparison with other countries/ regions}

In terms of distribution, the current study results were similar to those from related research on heart disease conducted in various countries in the Americas and Europe. For example, the high male:female ratio in Tianjin for mortality from CHD, particularly within the productive population (35-54 years old), was similar to CHD mortality results found in the Netherlands (3), and IHD mortality results found in Estonia and the United States $(10,11)$. A high ratio of male:female deaths from IHD and CHD has also been found in Brazil (the metro- politan areas of São Paulo and Niterói), Canada, Mexico, and the United States $(2,12-14)$.

In contrast to the results from Tianjin, there were significant declining trends in CHD mortality in the Americas and Europe. For example, between 1994 and 2005, age-adjusted CHD mortality decreased by $35 \%$ among inhabitants of Ontario, Canada (15); there was a $40 \%$ reduction in CHD mortality in most age groups for white men and women in Wisconsin from 1979 to 1998 (16); and 27 countries of the European Union experienced a decline in CHD mortality of $33 \%$ (in men) and $27 \%$ (in women) from 2000-2004 (17). In the United States and Canada, CHD mortality declined by about $60 \%$ for both sexes (1977-2000) (18). In Brazil, IHD mortality decreased $31 \%$ (in men) and 29.23 (in women) nationwide and 39\% (in men) and $46 \%$ (in women) in São Paulo from 1980 to 2005 (14). During 1997-2002, there were declines of up to $35 \%$ in deaths attributed to coronary heart disease in Cuba (19). These evidence-based data show that heart disease is preventable.

\section{DISCUSSION}

Since the 1970s, CHD mortality has been decreasing in various countries in the Americas and Europe $(3,20)$ but increasing in China $(7,21)$. China is currently undergoing the epidemiological transition that most developed countries experienced after World War II. With the development of its economy and the subsequent adoption of less healthy lifestyles, China's CHD burden has grown significantly. As of 2002, the prevalence of hyperlipidemia in China was $18.6 \%$, which means that more than 160 million adults had high levels of fat in their blood, putting them at risk for cardiovascular disease (22, 23). Between 1999 and 2008, CHD mortality rates rose slightly in Tianjin, while the proportion of CHD death rose significantly. Based on the results of this study, the proportion of outsidehospital CHD deaths was more than $50 \%$ in Tianjin, especially in rural areas. Outside-hospital deaths were attributed to CHD based on patient history and symptoms, which may have resulted in a slight overestimation of the mortality rate for this subgroup. The proportion of outside-hospital CHD deaths decreased during the study period.

People living in urban areas in Tianjin have higher CHD mortality rates than those living in rural areas. However, the high urban:rural ratio of CHD mortality observed at baseline declined significantly over the study period, suggesting that 1) the burden of CHD mortality is growing among the rural population and/or 2) the better-quality and more timely treatment that is available in urban areas has helped to decrease CHD mortality due to $\mathrm{CHD}$ among urban 


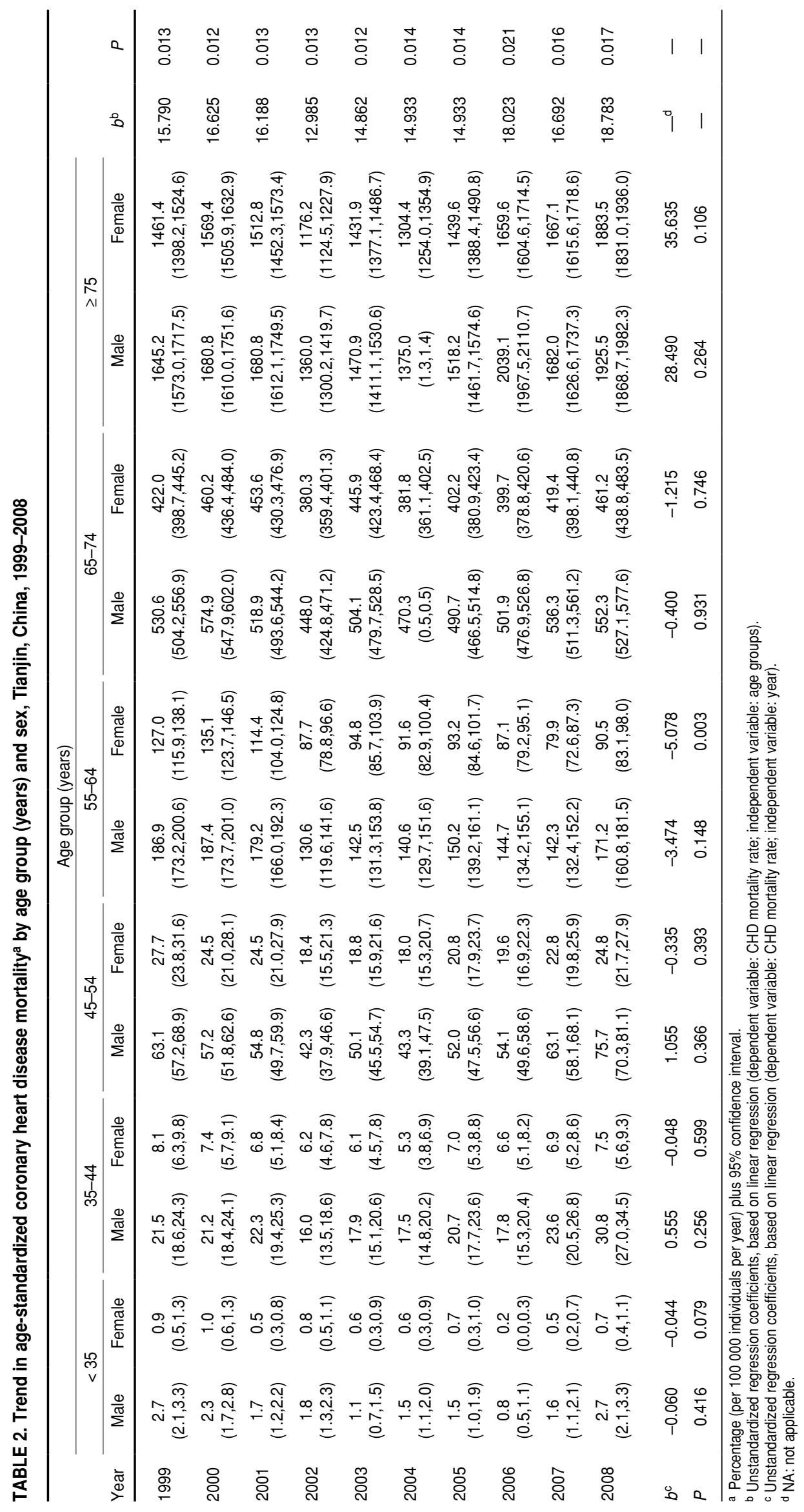


TABLE 3. Coronary heart disease mortality ${ }^{\mathrm{a}}$ occurring outside hospitals by sex, area of residence (urban versus rural), and age group, Tianjin, China, 1999-2008

\begin{tabular}{|c|c|c|c|c|c|c|c|c|c|c|c|c|c|c|c|}
\hline \multirow[b]{2}{*}{ Year } & \multirow{2}{*}{$\begin{array}{l}\text { Total } \\
(\%)\end{array}$} & \multirow{2}{*}{$\begin{array}{l}\text { Male } \\
(\%)^{b}\end{array}$} & \multirow{2}{*}{$\begin{array}{l}\text { Female } \\
(\%)^{b}\end{array}$} & \multirow{2}{*}{$\begin{array}{l}\text { Urban } \\
(\%)^{c}\end{array}$} & \multirow{2}{*}{$\begin{array}{l}\text { Rural } \\
(\%)^{c}\end{array}$} & \multirow{2}{*}{$\begin{array}{l}\text { Male:female } \\
\text { ratio }\end{array}$} & \multirow{2}{*}{$\begin{array}{l}\text { Urban:rural } \\
\text { ratio }\end{array}$} & \multicolumn{6}{|c|}{$\begin{array}{l}\text { Age group (years) } \\
(\%)\end{array}$} & \multirow[b]{2}{*}{$b^{d}$} & \multirow[b]{2}{*}{$P$} \\
\hline & & & & & & & & $<35$ & $35-44$ & $45-54$ & $55-64$ & $65-74$ & $\geq 75$ & & \\
\hline 2000 & 60.27 & 59.13 & 61.59 & 54.58 & 71.99 & 0.96 & 0.81 & 56.61 & 55.98 & 59.19 & 56.29 & 55.81 & 64.95 & 1.094 & 0.232 \\
\hline 2001 & 58.91 & 57.08 & 61.03 & 52.09 & 71.73 & 0.95 & 0.79 & 71.77 & 56.57 & 59.69 & 54.88 & 53.60 & 63.26 & -1.608 & 0.376 \\
\hline 2002 & 56.44 & 54.93 & 58.21 & 49.86 & 69.28 & 0.96 & 0.79 & 57.30 & 53.19 & 51.83 & 50.44 & 53.47 & 60.51 & 0.443 & 0.674 \\
\hline 2004 & 53.54 & 51.88 & 55.41 & 45.59 & 67.90 & 0.95 & 0.75 & 48.17 & 50.89 & 53.83 & 51.25 & 48.58 & 57.01 & 0.991 & 0.253 \\
\hline 2005 & 55.11 & 52.85 & 57.65 & 45.12 & 70.38 & 0.94 & 0.72 & 55.81 & 60.29 & 54.62 & 52.73 & 49.72 & 58.16 & -0.624 & 0.551 \\
\hline 2006 & 54.80 & 52.27 & 57.54 & 43.74 & 72.26 & 0.93 & 0.69 & 39.63 & 62.60 & 51.71 & 50.53 & 49.13 & 58.19 & 1.463 & 0.503 \\
\hline 2007 & 54.66 & 52.25 & 57.34 & 46.32 & 68.11 & 0.94 & 0.76 & 57.22 & 56.12 & 52.85 & 52.11 & 49.26 & 57.52 & -0.566 & 0.535 \\
\hline 2008 & 53.80 & 51.65 & 56.21 & 46.87 & 65.42 & 0.94 & 0.79 & 52.06 & 52.89 & 52.68 & 47.39 & 47.25 & 57.49 & 0.141 & 0.897 \\
\hline$P$ & 0.006 & 0.005 & 0.009 & 0.005 & 0.040 & 0.061 & 0.132 & 0.226 & 0.572 & 0.060 & 0.009 & 0.001 & 0.002 & - & - \\
\hline
\end{tabular}

a Percentage (per 100000 individuals per year) plus $95 \%$ confidence interval.

b Based on chi-square test (male/female); $P=0.000$.

c Based on chi-square test (urban/rural); $P=0.000$.

d Unstandardized regression coefficients, based on linear regression (dependent variable: proportion of CHD deaths occurring outside hospitals; independent variable: age groups).

e Unstandardized regression coefficients, based on linear regression (dependent variable: proportion of CHD deaths occurring outside hospitals; independent variable: year).

f NA: not applicable.

residents. The male:female ratio for deaths from CHD in Tianjin is also high. This disparity by sex may be caused by unique, sex-specific exposure to CHD risk factors such as smoking, drinking alcohol, and eating a poor diet. A study in Argentina showed that smokers had a relative risk of mortality due to CHD 2.2 times higher than that for non-smokers (24), and many evidence-based studies have shown that high consumption of salt and fat increases the risk of CHD. A Cuban study found that CHD mortality decreased along with declines in average per capita daily energy intake during the most severe economic crisis, and in the years immediately afterward (1997-2002) (19). In Tianjin, the male:female ratio for smoking was 7.7 (48.7\% versus 6.3\%), the male:female ratio for salt intake was 1.2 , and dietary fat intake among men was double the rate among women. This increasingly unhealthy lifestyle has led to a significant CHD burden among men.

\section{Current initiatives}

As part of China's national chronic disease prevention and control plan (25), the government is financing the provision of 18 primary public health care services for
Tianjin residents, including hypertension management, lifestyle interventions, and health education on disease prevention, and a large amount of financial support is being allocated to rural areas to promote improved medical services and primary health care for farmers. In addition, the TJCDC has developed the "Creating Smoke-Free Areas" project, which successfully lobbied the Tianjin People's Congress to pass a ban on smoking in indoor public places and workplaces. Behavior change interventions to disseminate information on the harmful effects of smoking and second-hand smoke are being implemented, and healthy diet programs have been put in place to advocate "lower salt, lower fat, more grains, more vegetables" to help decrease the risk of hypertension and hyperlipidemia as well as cardiovascular diseases.

\section{Recommendations}

The national chronic disease prevention and control plan is under way, but more interventions are needed. Given China's continuing economic growth and associated changes in lifestyle, management and control of CHD must be addressed in public health practices nationwide. A focus on primary prevention and control strategies needs to be incorporated into health practices in China to decrease the burden of CHD, including treatment and management of major risk factors such as high blood pressure, high blood cholesterol, tobacco use, unhealthy diet, physical inactivity, and diabetes. Successful strategies used to reduce CHD mortality in various developed countries could serve as a model. To reduce the significant CHD burden among men in Tianjin, and the associated labor productivity losses, CHD prevention programs should target the city's male population, particularly those of productive age (15-59 years old). In addition, based on the current study results, which indicate a rising trend in CHD mortality among rural residents in Tianjin, China should strengthen medical services and primary care in rural areas to prevent increasing mortality due to CHD among farmers.

\section{Conclusions}

As one of the largest cities in China, with a population of more than 10 million during 1999-2008 (a key period marked by epidemiological transition), 
including residents from both urban and rural areas, Tianjin is considered representative of the general Chinese population. Therefore, the results of the current study can be used to characterize CHD mortality more accurately nationwide as well as in Tianjin. Determining CHD mortality trends and distribution over the past decade in China is helpful considering the dramatic social and environmental changes that have occurred as a result of the country's rapid economic growth and urbanization. In addition, by providing data that can be generalized to a developing country as large as China, the current study results should help alleviate the current data gap for population-based trends and distributions of CHD mortality in low- and middle-income countries worldwide. Despite various limitations of the study's observational data (such as the lack of recorded risk behaviors for each death attributed to CHD), when combined with other epidemiological surveys or studies of CHD in China, the current results provide insight into CHD mortality risk factors and thus help provide guidance for future public health policies and practices targeting Tianjin and the country as a whole. Identification and control of population-specific CHD risk factors is crucial for decreasing the burden of CHD and other related cardiovascular diseases in China, and may also inform similar efforts in other developing countries.

Acknowledgment. The authors thank all staff members involved in the Tianjin Centers for Disease Control and Prevention (TJCDC) Cause-of-Death Registration System (CDRS).

\section{REFERENCES}

1. Mackay J, Mensah GA, Mendis S, Greenlund K; World Health Organization. The atlas of heart disease and stroke. Geneva: WHO; 2004. $112 \mathrm{pp}$.

2. Yusuf S, Reddy S, Ounpuu S, Anand S. Global burden of cardiovascular diseases: part I: general considerations, the epidemiologic transition, risk factors, and impact of urbanization. Circulation. 2001;104(22):2746-53.

3. Peeters A, Nusselder WJ, Stevenson C, Boyko EJ, Moon L, Tonkin A. Age-specific trends in cardiovascular mortality rates in the Netherlands between 1980 and 2009. Eur J Epidemiol. $2011 \mathrm{Feb}$ 6. [Epub ahead of print]

4. Wang $\mathrm{H}$, Steffen LM, Jacobs DR, Zhou X, Blackburn $\mathrm{H}$, Berger AK, et al. Trends in cardiovascular risk factor levels in the Minnesota Heart Survey (1980-2002) as compared with the National Health and Nutrition Examination Survey (1976-2002): a partial explanation for Minnesota's low cardiovascular disease mortality? Am J Epidemiol. 2011 Jan 27. [Epub ahead of print]

5. Sanderson JE, Mayosi B, Yusuf S, Reddy S, Hu $\mathrm{S}$, Chen Z, et al. Global burden of cardiovascular disease. Heart. 2007;93(10):1176-83.

6. Schooling CM, Lam TH, Ho SY, Mak KH, Leung GM. Does economic development contribute to sex differences in ischaemic heart disease mortality? Hong Kong as a natural experiment using a case-control study. BMC Public Health. 2008;8:32.

7. Critchley J, Liu J, Zhao D, Wei W, Capewell S. Explaining the increase in coronary heart disease mortality in Beijing between 1984 and 1999. Circulation. 2004;110(10):1236-44.

8. He J, Gu D, Wu X, Reynolds K, Duan X, Yao $C$, et al. Major causes of death among men and women in China. N Engl J Med. 2005;353(11):1124-34.

9. Gu D, Kelly TN, Wu X, Chen J, Duan X, Huang JF, et al. Blood pressure and risk of cardiovascular disease in Chinese men and women. Am J Hypertens. 2008;21(3):265-72.

10. Volozh OI, Zhdanov VS, Zhukovski GS, Solodkaya ES, Galakhov EE, Semenov AS, et al. Ischaemic heart disease in men of produc- tive age: comparison of epidemiological and morphological data. Cor Vasa. 1992;34(3): 199-208.

11. Devan AE, Umpierre $D$, Harrison ML, Lin HF, Tarumi T, Renzi CP, et al. Endothelial ischemia-reperfusion injury in humans: association with age and habitual exercise. Am J Physiol Heart Circ Physiol. 2011 Jan 14. [Epub ahead of print]

12. Escobedo-de la Peña J, Rodríguez-Ábrego G, Buitrón-Granados LV. Morbilidad y mortalidad por cardiopatía isquémica en el Instituto Mexicano del Seguro Social. Estudio ecológico de tendencias en población amparada por el Instituto Mexicano del Seguro Social entre 1990 y 2008. Arch Cardiol Mex. 2010;80(4):242-8

13. Rosa ML, Giro C, Alves Tde O, Moura EC, Lacerda Lda S, SantAnna LP, et al. Analysis of mortality and hospitalization for cardiovascular diseases in Niterói, between 1998 and 2007. Arq Bras Cardiol. 2011 Apr 29. [Epub ahead of print]

14. Mansur Ade P, Favarato D, Avakian SD Ramires JA. Trends in ischemic heart disease and stroke death ratios in Brazilian women and men. Clinics (Sao Paulo). 2010;65(11):1143-7.

15. Wijeysundera HC, Machado M, Farahati F, Wang $X$, Witteman $W$, van der Velde $G$, et al. Association of temporal trends in risk factors and treatment uptake with coronary heart disease mortality, 1994-2005. JAMA. 2010;303(18):1841-7.

16. Park H, Safdar N, Schmidt H. Decline in mortality of coronary heart disease among whites and blacks in Wisconsin 1979-1998. WMJ. 2002;101(3):23-7.

17. Levi F, Chatenoud L, Bertuccio P, Lucchini F, Negri E, La Vecchia C. Mortality from cardiovascular and cerebrovascular diseases in Europe and other areas of the world: an update. Eur J Cardiovasc Prev Rehabil. 2009;16(3):333-50.

18. Rodríguez T, Malvezzi M, Chatenoud L, Bosetti C, Levi F, Negri E, et al. Trends in mortality from coronary heart and cerebro- vascular diseases in the Americas: 1970-2000. Heart. 2006;92(4):453-60.

19. Franco M, Orduñez $P$, Caballero B, Tapia Granados JA, Lazo M, Bernal JL, et al. Impact of energy intake, physical activity, and population-wide weight loss on cardiovascular disease and diabetes mortality in Cuba, 19802005. Am J Epidemiol. 2007;166(12):1374-80.

20. Aspelund T, Gudnason V, Magnusdottir BT, Andersen K, Sigurdsson G, Thorsson B, et al. Analysing the large decline in coronary heart disease mortality in the Icelandic population aged 25-74 between the years 1981 and 2006. PLoS One. 2010;5(11):e13957.

21. Woo KS, Donnan SP. Epidemiology of coronary arterial disease in the Chinese. Int J Cardiol. 1989;24(1):83-93.

22. Wang LD. Report on National Survey of Nutrition and Health Status in 2002: comprehensive report. [Article in Chinese]. Vol. 1. Beijing: People's Health Press; 2005. Pp. 19-32.

23. Zhang XH, Lu ZL, Liu L. Coronary heart disease in China. Heart. 2008;94(9):1126-31.

24. Rubinstein A, Colantonio L, Bardach A, Caporale J, Martí SG, Kopitowski K, et al. Estimation of the burden of cardiovascular disease attributable to modifiable risk factors and cost-effectiveness analysis of preventative interventions to reduce this burden in Argentina. BMC Public Health. 2010;10(1):627.

25. Wang L, Kong L, Wu F, Bai Y, Burton R. Preventing chronic diseases in China. Lancet. 2005;366(9499):1821-4.

Manuscript received on 10 October 2010. Revised version accepted for publication on 14 September 2011. 
RESUMEN Objetivo. Examinar y describir la mortalidad por cardiopatía coronaria y su patrón de cambio (tendencia) por sexo, edad y zona de residencia (urbana frente a rural) en Tianjín, China, en el contexto de la transición epidemiológica, y compararla con las

Mortalidad por cardiopatía coronaria en China: edad, sexo y brechas entre la población urbana y la rural durante la transición epidemiológica

Palabras clave tendencias actuales en las Américas y Europa.

Métodos. Se analizaron 104393 casos de muertes debidas a cardiopatía coronaria ocurridas en Tianjín entre 1999 y 2008. Se codificó la mortalidad debida a cardiopatía coronaria según la Clasificación Internacional de Enfermedades (novena y décima revisiones). Se analizaron las tasas estandarizadas de mortalidad por cardiopatía coronaria y sus tendencias por edad, sexo y residencia urbana frente a rural.

Resultados. Durante el período de estudio, de 10 años, la proporción de la mortalidad total debida a cardiopatía coronaria registrada en Tianjín aumentó significativamente (de $16 \%$ a $24 \%$ ) y la mortalidad por cardiopatía coronaria estandarizada por edad aumentó levemente (sin significación estadística), en contraposición con las tendencias de mortalidad por cardiopatía coronaria observadas en diversos países de las Américas y Europa, que están descendiendo. No se encontraron diferencias en la tendencia de la mortalidad por cardiopatía coronaria por sexo en Tianjín. La mortalidad general por cardiopatía coronaria fue sistemáticamente más elevada en los grupos de mayor edad, los varones y los residentes de zonas urbanas. La proporción de muertes debidas a cardiopatía coronaria que ocurrieron fuera de los hospitales fue de $55,81 \%$, con una tendencia decreciente en el período de estudio. Esta proporción fue mayor en las zonas rurales que en las urbanas, pero no se encontró diferencia entre los distintos grupos de edad.

Conclusiones. Desde 1999 hasta el 2008, la mortalidad por cardiopatía coronaria en Tianjín varió según el sexo, la edad y la residencia urbana frente a la rural. Se recomienda efectuar nuevas investigaciones para identificar los factores de riesgo de cardiopatía coronaria y las poblaciones más vulnerables a la enfermedad, a fin de mejorar la prevención de la cardiopatía coronaria. Deben elaborarse estrategias para controlar la enfermedad similares a las usadas en varios países desarrollados de las Américas y Europa para reducir la carga de cardiopatía coronaria en China.

Enfermedad coronaria, mortalidad; transición epidemiológica; factores de riesgo; China. 